\title{
Konrad Wnęk
}

Uniwersytet Jagielloński, Wydział Historyczny

email:wnek@hist.uj.edu.pl

\section{Metoda badania wiarygodności masowych źródeł historycznych, baz danych i opracowań badawczych}

\section{Method of testing the reliability of mass historical sources, databases and research studies}

\begin{abstract}
Abstrakt
$\mathrm{W}$ artykule przedstawiono koncepcję zastosowania prawa Benforda do sprawdzania wiarygodności źródeł historycznych o charakterze masowym oraz do wykrywania ewentualnych fałszerstw, które mogłyby się pojawić w opracowaniach naukowych zawierających dużo danych liczbowych. W celu sprawdzenia możliwości zaimplementowania w badaniach historycznych poddano analizie jedno źródło historyczne, dwa opracowania badawcze i jedną bazę danych. W wyniku przeprowadzonych prób zgromadzono materiał statystyczny, który porównano z rozkładem Benforda dla wiodącej cyfry. Potwierdzono możliwość prowadzenia wewnętrznej krytyki źródeł masowych oraz zaproponowano syntetyczne miary będące narzędziem weryfikacji rzetelności źródeł, w których występuje wiele danych liczbowych.
\end{abstract}

\begin{abstract}
The article presents the idea of applying Benford's law to check the reliability of historical sources of mass character and to detect possible adulterations that could appear in scientific studies containing large amounts of numerical data. In order to verify the feasibility of implementation in historical research, the analysis has been based on one historical source, two research studies and one database. As a result of the tests, statistical material was collected and then compared with the Benford distribution for the leading number. The possibility of conducting internal criticism of mass sources was confirmed and synthetic measures were proposed as a tool for verifying the reliability of sources, in which many numerical data are present.
\end{abstract}


Historycy, oprócz wykorzystywania tekstowych źródeł typu narracyjnego, coraz częściej sięgają również do innych materiałów. Są to zarówno dane zaczerpnięte $\mathrm{z}$ wywiadów, będące podstawą historii mówionej, jak i różnego rodzaju dane o charakterze liczbowym. Źródła masowe zagościły na dobre w badaniach historycznych już ponad 100 lat temu, ale do tej pory budzą one wśród uczonych kontrowersje. $Z$ jednej strony są traktowane jako zimny statystyczny materiał, który oddala badacza od człowieka będącego obiektem poznania historycznego, z drugiej znalazły grono oddanych zwolenników chcących zobiektywizować badania historyczne i nadać im zbliżony do nauk ścisłych i przyrodniczych kształt.

Rozbudowane tablice statystyczne, bazy danych z tysiącami rekordów czy opracowania zawierające setki liczb niekoniecznie jednak muszą być bardziej wiarygodne od jednozdaniowych wzmianek pochodzących ze średniowiecznych kronik. U doświadczonego badacza zjawisk masowych nieraz pojawia się myśl, czy te tysiące liczb, którymi operuje, są prawdziwe. Czy zostały one rzetelnie zebrane, a później opracowane, a może pisarz czy urzędnik chciał zaoszczędzić sobie pracy i wpisywał je „na chybił trafił”? Część z tych wątpliwości może rozwiać prawidłowo przeprowadzona krytyka źródeł. Rozważania odnośnie do tej kwestii były zresztą już prowadzone przez metodologów historii ${ }^{1}$, ale czy istnieje jakiś obiektywny sposób na sprawdzenie wiarygodności materiału źródłowego wytworzonego w przeszłości? W demografii historycznej spotyka się takie wskaźniki, opierające się w dużej mierze na sprawdzonych parametrach, takich jak stosunek liczby urodzeń do liczby małżeństw, frakcja urodzonych chłopców, stosunek liczby urodzeń bliźniaczych do ogółu urodzeń itp. Wciąż jednak obracamy się w kręgu wąskiej specjalności, która jest dość hermetyczna dla większości historyków. Czy istnieje zatem jakaś ogólna prawidłowość, która pozwala na weryfikację danych liczbowych? Owszem, niektóre zjawiska mają rozkład normalny (Gaussa), jak np. wzrost. Badacz może na podstawie różnic pomiędzy teoretycznym rozkładem a danymi empirycznymi pochodzącymi ze źródeł oszacować, czy w źródle znajdują się jednostki pochodzące z całej populacji.

Niewielu jednak zdaje sobie sprawę z tego, że istnieje dość uniwersalna metoda sprawdzania poprawności danych liczbowych. Bazuje ona na prawie Benforda $\mathrm{i}$ jest stosowana przy wykrywaniu fałszerstw ksiąg rachunkowych, zeznań podatkowych, sondaży ${ }^{2}$, ale także w przypadku weryfikacji wyników wyborów

\footnotetext{
${ }^{1}$ Witold Kula, Problemy i metody historii gospodarczej (Warszawa: PWN, 1963), 355-360.

2 George Judge, Laura Schechter, „Detecting Problems in Survey Data Using Benford's Law”, The Journal of Human Resources 44 (2009), 1: 1-24, dostęp 20.03.2017, http://www.jstor.org/stable/20648886.
} 
parlamentarnych ${ }^{3}$. Intuicja podpowiada nam, że prawdopodobieństwo występowaniu różnych cyfr powinno być takie samo, czyli 1 wystąpi tak samo często jak 2 lub 8, jednak w przypadku pierwszej cyfry danej liczby (tzw. wiodącej) nie jest to prawda. Niektóre cyfry są używane częściej niż inne, fałszerz - szczególnie w dawnych czasach - nigdy nie słyszał o rozkładzie Benforda i gdy próbował zmieniać dane, robił to tak, aby nie powtarzać zbyt wiele razy jednej cyfry. Wynika $\mathrm{z}$ tego, że zmanipulowane źródła będą obciążone błędem spowodowanym próbą wytworzenia danych. Będą po prostu zbyt losowe, jakby to dziwnie nie brzmiało - zbyt dobre lub zbyt intuicyjnie prawdopodobne.

Jak często bywa z odkryciami, prawo Benforda zostało odkryte już wcześniej przez innego badacza - Simona Newcomba ${ }^{4}$, który w 1881 roku na łamach „American Journal of Mathematics" opublikował artykuł na temat dziwnego występowania cyfr wiodących ${ }^{5}$. Obserwacja ta długo pozostawała ciekawostką matematyczną bez uzasadnienia teoretycznego. Zresztą samo odkrycie tej prawidłowości również było w dużej mierze dziełem przypadku - otóż Newcomb zauważył, że tablice logarytmiczne są częściej używane na początku, a przecież czytelnicy powinni brać pod uwagę różne cyfry. Początek książki zawierającej tablice logarytmiczne był bardziej zniszczony, co doprowadziło go do wniosku, że najczęściej sprawdzana w nich liczba zaczyna się od cyfry 1 . Druga cyfra również charakteryzowała się różną częstością występowania, natomiast trzecia i kolejne nie były już zróżnicowane. Newcomb jednak nie przeprowadził intensywniejszych badań nad tym zjawiskiem i przez dłuższy czas pozostawało ono tylko ciekawostką.

${ }^{3}$ Luis Pericchi, David Torres, „Quick Anomaly Detection by the Newcomb-Benford Law, with Applications to Electoral Processes Data from the USA, Puerto Rico and Venezuela", Statistical Science 26 (2011), 4: 502-516, dostęp 20.03.2017, http://www.jstor.org/stable/23208738.

${ }^{4}$ William Wallace Campbell, Biographical memoir Simon Newcomb 1835-1909 (National Academy of Sciences, 1916), dostęp 20.03.2017, http://www.nasonline.org/publications/biographical-memoirs/memoir-pdfs/newcomb-simon.pdf; Arthur L. Norberg, „Simon Newcomb's Early Astronomical Career", Isis 69 (1978), 2: 209-225, dostęp 20.03.2017, http://www.jstor.org/ stable/230430.

${ }^{5}$ Simon Newcomb, „Note on the Frequency of Use of the Different Digits in Natural Numbers”, American Journal of Mathematics 4 (1881), 1: 39-40. 
Tabela 1. Rozkład pierwszej (wiodącej) i drugiej cyfry według Simona Newcomba

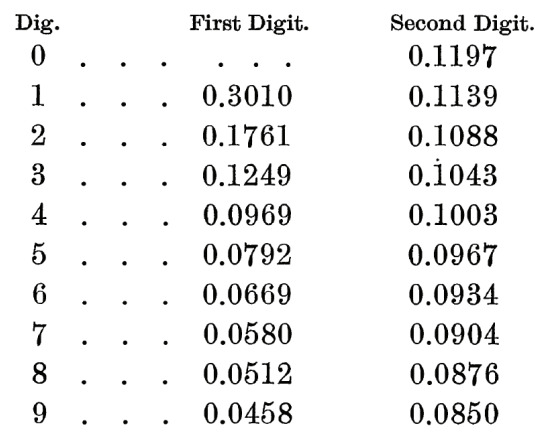

Źródło: Newcomb, „Note on the Frequency”, 40.

Dopiero Frank Benford rozpoczął dogłębne studia nad tą anomalią i sformułował podstawy matematyczne tego dziwnego rozkładu 6 . Okazało się, że z różnym natężeniem występuje on w przypadku takich zmiennych, jak: liczba ludności, powierzchnia rzek, ciśnienie atmosferyczne itd. Prawo Benforda działa dla wielkości, których logarytmy są rozłożone równomiernie, czyli zeznań podatkowych, gazet, prac naukowych zawierających wiele liczb, natomiast nie działa dla liczb losowych (np. nie sprawdzi się przy Lotto i w innych grach opartych na rozkładzie losowym) oraz dla zjawisk zbliżonych do rozkładu normalnego (np. wzrost, IQ). Co ciekawe, działa też w przypadku pomieszania liczb pochodzących z różnych rozkładów. Rozkład Benforda ma charakter dyskretny dla cyfr od 1 do 9 i można go przedstawić wzorem:

$$
P(D)=\log \left(1+\frac{1}{D}\right)
$$

gdzie, $\mathrm{D}=(1, \ldots, 9)$.

${ }^{6}$ Frank Benford, „The Law of Anomalous Numbers”, Proceedings of the American Philosophical Society 78 (1938), 4: 551-572. 
Tabela 2. Występowanie cyfr wiodących w różnych grupach danych (\%)

Percentage of Times the Natural Numbers 1 to 9 are Used as First Digits in Numbers, as Determined by 20,229 Observations

\begin{tabular}{|c|c|c|c|c|c|c|c|c|c|c|c|}
\hline \multirow{2}{*}{$\begin{array}{l}\text { Oे } \\
\text { ర్ }\end{array}$} & \multirow{2}{*}{ Title } & \multicolumn{9}{|c|}{ First Digit } & \multirow{2}{*}{ Count } \\
\hline & & 1 & 2 & 3 & 4 & 5 & 6 & 7 & 8 & 9 & \\
\hline A & Rivers, Area & 31.0 & 16.4 & 10.7 & 11.3 & 7.2 & 8.6 & 5.5 & 4.2 & 5.1 & 335 \\
\hline $\mathrm{B}$ & Population & 33.9 & 20.4 & 14.2 & 8.1 & 7.2 & 0 & 1 & 3.7 & 2.2 & 3259 \\
\hline $\mathrm{C}$ & Constants & 41.3 & 14.4 & 4.8 & 8.6 & 10.6 & 5. & 1.0 & 2.9 & 10.6 & 104 \\
\hline D & Newspapers & 30.0 & 18.0 & 12.0 & 10.0 & 8.0 & 6.0 & 6.0 & 5.0 & 5.0 & 100 \\
\hline $\mathrm{E}$ & Spec. Heat & 24.0 & 18.4 & 16.2 & 14.6 & 10.6 & 4.1 & 3.2 & 4.8 & 4.1 & 1389 \\
\hline $\mathrm{F}$ & Pressure & 29.6 & 18.3 & 12.8 & 9.8 & 8.3 & 6 & 5.7 & 4.4 & 4.7 & 703 \\
\hline $\mathrm{G}$ & H.P. Lost & 30.0 & 18.4 & 11.9 & 10.8 & 8 & & & & 3.6 & 690 \\
\hline $\mathrm{H}$ & Mol. Wgt. & 26.7 & 25.2 & 15.4 & 10.8 & 6.7 & 5. & 1 & 2 & 3.2 & 1800 \\
\hline I & Drainage & 27.1 & 23.9 & 13.8 & 12.6 & 8.2 & 5.0 & 5.0 & 2.5 & 1.9 & 159 \\
\hline $\mathbf{J}$ & Atomic Wgt. & 47.2 & 18.7 & 5.5 & 4.4 & 6.6 & 4.4 & 3.3 & 4. & 5.5 & 91 \\
\hline K & $n^{-1}, \sqrt{n}, \cdots$ & 25.7 & 20.3 & 9.7 & 6.8 & 6.6 & 6.8 & 7.2 & 8 & .9 & 5000 \\
\hline $\mathrm{L}$ & Design & 26.8 & 14.8 & 14.3 & 7.5 & 8.3 & 8. & 7.0 & 7 & 5.6 & 560 \\
\hline M & Digest & 33.4 & 18.5 & 12.4 & 7.5 & 7.1 & 6.5 & 5.5 & 4.9 & 4.2 & 308 \\
\hline $\mathrm{N}$ & Cost Data & 32.4 & 18.8 & 10.1 & 10.1 & 9.8 & 5. & 4.7 & 5 & 3.1 & 741 \\
\hline $\mathrm{O}$ & X-Ray Volts & 27.9 & 17.5 & 14.4 & 9.0 & 8.1 & 7.4 & 5.1 & 5 . & 4.8 & 707 \\
\hline $\mathbf{P}$ & Am. League & 32.7 & 17.6 & 12.6 & 9.8 & 7.4 & 6. & 4.9 & 5 . & 3.0 & 1458 \\
\hline $\mathrm{Q}$ & Black Body & 31.0 & 17.3 & 14.1 & 8.7 & 6.6 & 7. & 5.2 & 4 & 5.4 & 1165 \\
\hline $\mathrm{R}$ & ddresses & 28.9 & 19.2 & 12.6 & 8.8 & 8.5 & 6.4 & 5.6 & 5.0 & 5.0 & 342 \\
\hline $\mathrm{S}$ & $n^{1}, n^{2} \cdots n !$ & 25.3 & 16.0 & 12.0 & 10.0 & 8.5 & 8.8 & 6.8 & 7.1 & 5.5 & 900 \\
\hline $\mathrm{T}$ & Death Rate & 27.0 & 18.6 & 15.7 & 9.4 & 6.7 & 6.5 & 7.2 & 4.8 & 4.1 & 418 \\
\hline \multirow{2}{*}{\multicolumn{2}{|c|}{$\begin{array}{l}\text { Average. ....... } \\
\text { Probable Error }\end{array}$}} & & & & & & & & & & 1011 \\
\hline & & \pm 0.8 & \pm 0.4 & \pm 0.4 & \pm 0.3 & \pm 0.2 & \pm 0.2 & \pm 0.2 & \pm 0.2 & \pm 0.3 & 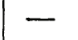 \\
\hline
\end{tabular}

Źródło: Benford, „The Law”, 553.

Tabela 3. Rozkład Benforda

\begin{tabular}{cc}
\hline Cyfra wiodąca D & Frakcja P(D) \\
\hline 1 & 0,301 \\
2 & 0,176 \\
3 & 0,125 \\
4 & 0,097 \\
5 & 0,079 \\
6 & 0,067 \\
7 & 0,056 \\
8 & 0,051 \\
9 & 0,046 \\
\hline
\end{tabular}

Opracowanie własne. 
Obecnie istnieje już całkiem pokaźna liczba prac, które odnoszą się do prawa Benforda ${ }^{7}$, jakkolwiek matematyczny dowód i ostateczne wyjaśnienie tego zjawiska zostało opublikowane dopiero w 1995 roku$^{8}$. Rozkład ten powinien się również sprawdzić przy analizie źródeł i opracowań historycznych, o ile zawierają dużo liczb. W Polsce już od wielu lat sprawnie przebiega digitalizacja źródeł, także o charakterze masowym. Niektórzy badacze publikują je w bibliotekach cyfrowych, drudzy wolą tworzone przez siebie strony internetowe, inni zaś preferują międzynarodowe repozytoria danych. Podobnie jest z publikacjami naukowymi, które często są już dostępne również $\mathrm{w}$ wersjach elektronicznych w postaci plików PDF. Z takich źródeł i opracowań można w łatwy sposób wyodrębnić dane liczbowe, a potem spróbować porównać, czy spełniają one założenie o zbliżonym rozkładzie cyfr wiodących.

Jednym z łatwo dostępnych źródeł o charakterze masowym jest baza danych zawierająca informacje podatkowe z końca XVI wieku, „Rejestry poborowe województwa kaliskiego"9. W celu weryfikacji wiarygodności źródła wykorzystano dane z powiatu kcyńskiego z 1591 roku $^{10}$, a pobrany plik w formacie arkusza kalkulacyjnego Excel łatwo dał się przetworzyć do potrzebnej formy. Najpierw usunięto dane nienumeryczne, następnie zlikwidowano miejsca dziesiętne oraz usunięto 0 przed przecinkiem, po czym wszystkie dane liczbowe przeniesiono do jednej kolumny. W sąsiedniej kolumnie, przy pomocy funkcji tekstowej, wyodrębniono cyfrę wiodącą, którą pogrupowano według jej wartości. W efekcie uzyskano rozkład cyfr wiodących w liczbach bezwzględnych i względnych, które porównano z teoretycznym rozkładem Benforda. Wyniki tych obliczeń zamieszczono w tabeli 4.

Różnice między spodziewanym a empirycznym rozkładem cyfry wiodącej są niewielkie, zaobserwowano jedynie nadreprezentację cyfry 1 i niewielki niedobór przy 7, 8 i 9. Jak na źródła typu podatkowego odchylenia te są naprawdę nieznaczne i nie dają podstaw do przypuszczeń, że źródło zostało sfałszowane. Oceny tej dokonano jednak bez zastosowania jakiegokolwiek aparatu statystycznego,

\footnotetext{
${ }^{7}$ Rachel M. Fewster, „A Simple Explanation of Benford's Law”, The American Statistician 63 (2009), 1: 26-32, dostęp 20.03.2017, http://www.jstor.org/stable/27644089; Jonothan L. Logan, Samuel A. Goudsmit, „The First Digit Phenomenon”, Proceedings of the American Philosophical Society 122 (1978), 4: 193-197, dostęp 20.03.2017, http://www.jstor.org/stable/986530; Persi Diaconis, „The Distribution of Leading Digits and Uniform Distribution Mod 1”, The Annals of Probability 5 (1977), 1: 72-81, dostęp 20.03.2017, http://www.jstor.org/stable/2242803; Ralph A. Raimi, „The First Digit Problem”, The American Mathematical Monthly 83 (1976), 7: 521-538; tenże, „The First Digit Phenomenon Again", Proceedings of the American Philosophical Society 129 (1985), 2: 211-219, dostęp 20.03.2017, http://www.jstor.org/stable/986989.

${ }^{8}$ Theodore P. Hill, „Base-invariance Implies Benford's Law”, Proceedings of the American Mathematical Society 123 (1995), 3: 887-895.

${ }^{9} \mathrm{http}: / /$ atlasfontium.pl/index.php?article=kaliskie, dostęp 15.03.2017.

${ }^{10} \mathrm{http} / / /$ hgisb.kul.lublin.pl/agad/rejestry/rejestry_kcn16w.xls, dostęp 15.03.2017.
} 
gdyż jego dobór zależy między innymi od liczebności próby. O sposobach bardziej zobiektywizowanych miar będzie mowa w dalszej części artykułu. Warto również zwrócić uwagę na fakt, że otrzymane wartości wydają się być bardziej zgodne z rozkładem liczby ludności w różnych miejscowościach analizowanych przez Benforda (tab. 2).

Następnie podobnie postąpiono $\mathrm{z}$ dwiema opublikowanymi pracami zawierającymi wiele danych liczbowych - pierwsza to książka autorstwa Konrada Wnęka, a druga Mikołaja Szołtyska. Uzyskane rozkłady nie odbiegają znacznie od wyników uzyskanych w pierwszym przypadku, zauważalna jest nadmiarowość cyfry 1 i niewielkie odstępstwa przy pozostałych cyfrach.

Tabela 4. Cyfry wiodące w „Rejestrze poborowym województwa kaliskiego”, powiat kcyński 1591 rok

\begin{tabular}{ccc}
\hline Cyfra wiodąca & Liczebność & Liczebność (\%) \\
\hline 1 & 438 & 35,1 \\
2 & 239 & 19,1 \\
3 & 151 & 12,1 \\
4 & 123 & 9,8 \\
5 & 90 & 7,2 \\
6 & 80 & 6,4 \\
7 & 52 & 4,2 \\
8 & 45 & 3,6 \\
9 & 31 & 2,5 \\
\hline Ogółem & 1249 & 100,0 \\
\hline
\end{tabular}

Źródło: http://hgisb.kul.lublin.pl/agad/rejestry/rejestry_kcn16w.xls; obliczenia własne.

Tabela 5. Cyfry wiodące w pracy Konrada Wnęka

\begin{tabular}{ccc}
\hline Cyfra wiodąca & Liczebność & Liczebność (\%) \\
\hline 1 & 3635 & 35,3 \\
2 & 1751 & 17,0 \\
3 & 1391 & 13,5 \\
4 & 737 & 7,2 \\
5 & 745 & 7,2 \\
6 & 553 & 5,4 \\
7 & 589 & 5,7 \\
8 & 509 & 4,9 \\
9 & 379 & 3,7 \\
\hline Ogółem & 10289 & 100,0 \\
\hline
\end{tabular}

Źródło: Konrad Wnęk, Własność nieruchomości w Krakowie w połowie XIX w. (Kraków: Historia Iagellonica, 2011); obliczenia własne. 
Tabela 6. Cyfry wiodące w pracy Mikołaja Szołtyska

\begin{tabular}{ccc}
\hline Cyfra wiodąca & Liczebność & Liczebność (\%) \\
\hline 1 & 16291 & 35,2 \\
2 & 7888 & 17,1 \\
3 & 4812 & 10,4 \\
4 & 3792 & 8,2 \\
5 & 3313 & 7,2 \\
6 & 2899 & 6,3 \\
7 & 2550 & 5,5 \\
8 & 2242 & 4,8 \\
9 & 2470 & 5,3 \\
\hline Ogółem & 46257 & 100,0 \\
\hline
\end{tabular}

Źródło: Mikołaj Szołtysek, Rethinking East-Central Europe: Family Systems and Co-residence in the Polish-Lithuanian Commonwealth, vol. 1-2 (Bern: Peter Lang, 2015); obliczenia własne.

Tabela 7. Cyfry wiodące bazy danych spisu ludności z Rostocku w 1900 roku

\begin{tabular}{ccc}
\hline Cyfra wiodąca & Liczebność & Liczebność (\%) \\
\hline 1 & 347894 & 42,3 \\
2 & 177822 & 21,6 \\
3 & 29630 & 3,6 \\
4 & 16773 & 2,0 \\
5 & 20250 & 2,5 \\
6 & 143991 & 17,5 \\
7 & 46920 & 5,7 \\
8 & 7358 & 0,9 \\
9 & 32578 & 4,0 \\
\hline Ogółem & 823216 & 100,0 \\
\hline
\end{tabular}

Źródło: http://www.censusmosaic.org/mosaic/tmp/download/Datafile_06\%20Version\%201.0.zip, dostęp 15.03.2017.

Ciekawszy natomiast jest kolejny analizowany zbiór danych, pochodzący $\mathrm{z}$ bazy danych projektu MOSAIC. Jest to zapis wyników spisu ludności Rostocku z 1900 roku. Baza danych z MOSAIC w zupełności odbiega od rozkładu Benforda i można w pierwszej chwili odnieść wrażenie, że wystąpił jakiś problem z danymi lub że zostały one po prostu sfałszowane. Nie to jest jednak przyczyną tak dziwnej dystrybucji cyfr wiodących. Spowodowane zostało to wykorzystaniem liczb do kodowania informacji, które w źródle były informacjami typu jakościowego, np. obecność w czasie spisu została zakodowana jako cyfra 1, co dało znaczącą przewagę i przyczyniło się do zmiany dystrybucji cyfr wiodących. Podobnie rzecz ma się z innymi danymi, jak płeć, stan cywilny i wyznanie. Nie można 
zatem stosować tej metody dla danych jakościowych, które bądź pierwotnie, bądź wtórnie zostały zakodowane.

Podsumowanie różnic między powyższymi czterema zbiorami danych zostało ujęte syntetycznie na wykresie 1, na którym wyraźnie widać, że najbardziej podejrzaną dystrybucją cyfr wiodących charakteryzuje się baza danych z MOSAIC. Wynika to, jak już wspomniano, z zastosowania kodowania danych, należy więc podkreślić, że prawo Benforda nadaje się do testowania poprawności danych źródłowych pierwotnych, niezakodowanych. Można weryfikować przy

Wykres 1. Porównanie dystrybucji cyfr wiodących w różnych zbiorach danych $\mathrm{z}$ dystrybucją Benforda (\%)

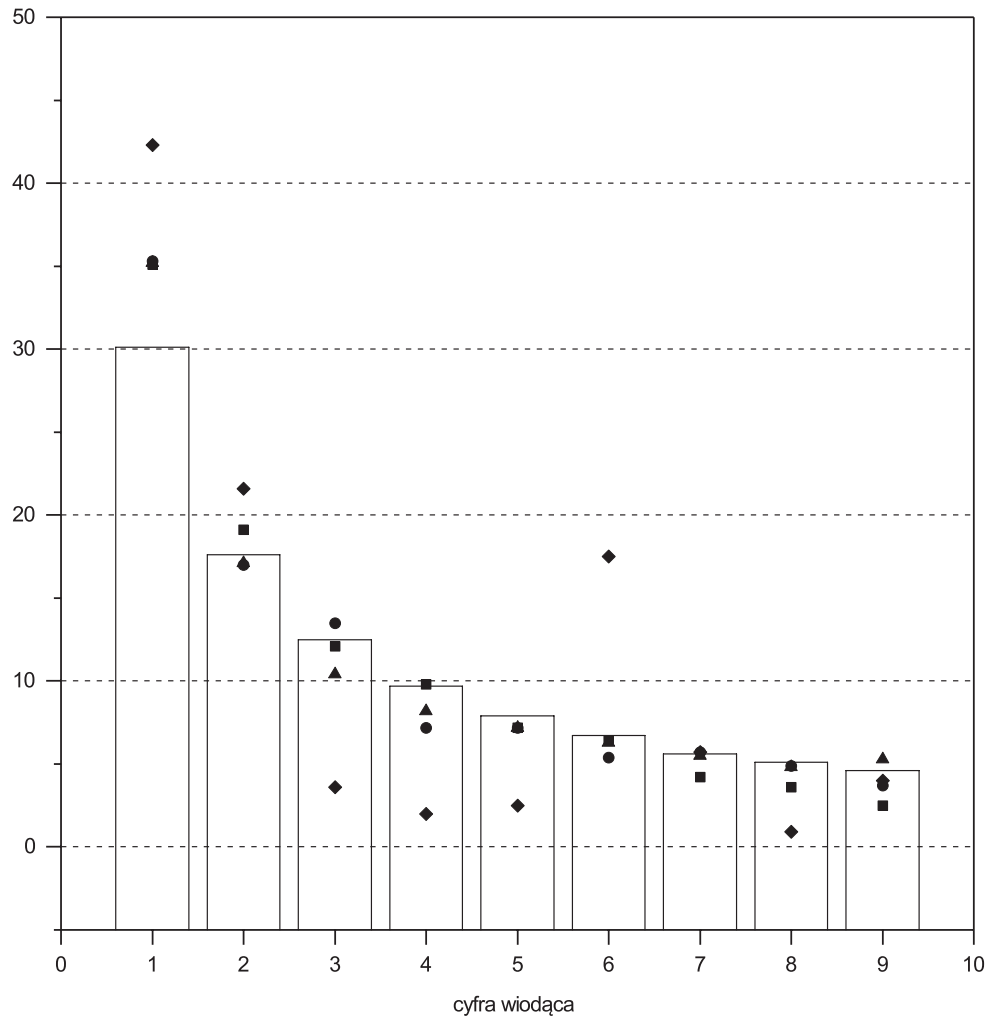

$$
\begin{array}{ll}
\text { - Rejestr } \\
\text { - Wnęk } \\
\text { - Szołtysek } \\
\text { - Rostock } \\
\hline & \text { Benford }
\end{array}
$$

Źródło: http://hgisb.kul.lublin.pl/agad/rejestry/rejestry_kcn16w.xls; Wnęk, Własność; Szołtysek, Rethinking; http://www.censusmosaic.org/mosaic/tmp/download/Datafile_06\%20Version $\% 201$. 0.zip; obliczenia własne. 
jego pomocy prace zaliczeniowe, magisterskie, doktorskie itd. z dużą liczbą danych kwantytatywnych. Jak widać, samo wykorzystanie metody nie rozwiązuje wszystkich problemów związanych z określeniem prawdziwości danych. Test nie wykaże też, co zostało zmienione, wiadomo tylko, że liczby, ale nie wiadomo, czy źródłowe, czy przy opracowaniu wyników badań. Należy zatem być ostrożnym przy wyciąganiu wniosków, nieprawidłowa dystrybucja cyfr może być bowiem spowodowana innymi niż fałszerstwo czynnikami, np. kodowaniem.

Problemem jest również znalezienie obiektywnej miary pozwalającej stwierdzić, czy dane są wiarygodne. Można próbować zastosować np. test chi-kwadrat, jednakże przy dużych zbiorach danych nawet nieznaczna różnica może być uznana za istotną statystycznie. Historykowi przydałoby się inne narzędzie, które pomogłoby mu nie tylko w określeniu, czy dane źródłowe są prawidłowe, ale także dawałoby wskazówki, w jakim stopniu zostały one zmienione. Wreszcie pozostaje pytanie, czy stosować klasyczną dystrybucję Benforda, czy też skorzystać z tej zaobserwowanej $\mathrm{w}$ rzetelnych badaniach $\mathrm{z}$ wykorzystaniem źródeł masowych. W celu porównania rozkładów zdecydowano się wykorzystać dywergencję Kullbacka-Leiblera ${ }^{11}$ (nazywaną często entropią względną), która jest prosta w obliczeniach i pozwala na określenie różnic między dwoma rozkładami, również o charakterze dyskretnym. Wyraża się ona wzorem:

$$
D_{K L}(p(x) \| q(x))=\sum_{x \in X} p(x) \ln \frac{p(x)}{q(x)} .
$$

Jej wartości teoretyczne mogą się zawierać pomiędzy 0 a 1 , przy czym 0 uzyskujemy w przypadku identycznych rozkładów, zaś 1 - gdy są one całkowicie odmienne. Oczywiście jest mało prawdopodobne, że rzeczywiste rozkłady będą takimi właśnie przypadkami. Niestety w przeciwieństwie do znanych parametrów statystycznych, jak na przykład współczynnik korelacji, nie ma ustalonego punktu odniesienia, do którego można porównać otrzymane wyniki. Dlatego postanowiono sprawdzić, jakie wyniki obliczeń entropii względnej zostaną uzyskane z analizowanych już wcześniej zbiorów danych. Otrzymane wyniki (tab. 8) nie stanowią zbytniego zaskoczenia; zbiory danych, które na wykresie nie odbiegały zbytnio od dystrybucji Benforda, nie wykazują wysokich wartości dywergencji i nie przekraczają 0,02 . Natomiast dla danych z MOSAIC wynik jest już mocno odbiegający od poprzednich i wynosi 0,23 . 1991).

${ }^{11}$ Thomas M. Cover, Joy A. Thomas, Elements of Information Theory (New York: Wiley, 
Tabela 8. Dywergencja Kullbacka-Leiblera dla wybranych zbiorów danych w stosunku do dystrybucji Benforda

\begin{tabular}{lc}
\hline \multicolumn{1}{c}{ Zbiór danych } & KL \\
\hline Rejestr z 1591 & 0,016 \\
Wnęk & 0,010 \\
Szołtysek & 0,008 \\
MOSAIC & 0,229 \\
\hline
\end{tabular}

Opracowanie własne.

Podobnie się dzieje, gdy obliczymy dywergencję w stosunku do pracy z zakresu historii gospodarczej (tab. 9); mniej więcej te same wyniki można uzyskać biorąc za podstawę odniesienia którąkolwiek z wymienionych wcześniej prac.

Tabela 9. Dywergencja Kullbacka-Leiblera dla wybranych zbiorów danych w stosunku do dystrybucji cyfr wiodących z pracy Konrada Wnęka

\begin{tabular}{lc}
\hline \multicolumn{1}{c}{ Zbiór danych } & KL \\
\hline Rejestr z 1591 & 0,017 \\
Wnęk & 0,000 \\
Szołtysek & 0,012 \\
MOSAIC & 0,226 \\
\hline
\end{tabular}

Opracowanie własne.

Dalej jednak nie można ustalić, jaka jest wartość graniczna, od której można mieć uzasadnione podejrzenia o manipulację danymi. Aby sprawdzić, jak zachowuje się wskaźnik entropii względnej przy intencjonalnej zmianie danych, zmodyfikowano część danych z pracy Konrada Wnęka, dodając stopniowo coraz więcej danych o rozkładzie losowym cyfry wiodącej. Dodatkowo ujęto w tabeli indeks W, który jest wynikiem iloczynu KL i stałej 557,95, będącej stosunkiem liczby 100 do 0,179 (KL) uzyskanej przy założeniu losowego rozkładu cyfr od 1 do 9. Tak uzyskany wskaźnik przyjmuje wartość 100 przy zupełnie losowym rozkładzie cyfr wiodących, ale może go przekroczyć, gdy rozkład będzie zbliżał się do odwrotnego w stosunku do rozkładu Benforda. 
Tabela 10. Dywergencja Kullbacka-Leiblera dystrybucji cyfr wiodących z pracy Konrada Wnęka ze stopniowym udziałem losowych cyfr wiodących

\begin{tabular}{ccc}
\hline Udział zmodyfikowanych danych (\%) & KL & W \\
\hline $0^{\text {a }}$ & 0,010 & 5,53 \\
10 & 0,002 & 1,32 \\
20 & 0,008 & 4,63 \\
30 & 0,017 & 9,70 \\
40 & 0,030 & 16,62 \\
50 & 0,049 & 27,42 \\
60 & 0,068 & 37,96 \\
70 & 0,093 & 51,91 \\
80 & 0,119 & 66,57 \\
90 & 0,154 & 86,15 \\
$100^{\mathrm{b}}$ & 0,179 & 100,00 \\
\hline
\end{tabular}

a Dane oryginalne bez modyfikacji.

${ }^{\mathrm{b}}$ Wszystkie dane o rozkładzie losowym cyfry wiodącej.

Opracowanie własne.

Jak wynika $\mathrm{z}$ danych $\mathrm{w}$ tabeli 10, wzrost udziału danych o charakterze losowym wpływa zarówno na uzyskane wyniki dywergencji KL, jak i zastosowany wskaźnik rzetelności danych. Należy przy tym wyjaśnić, dlaczego dodanie $10 \%$ danych losowych wpłynęło pozytywnie na wartość wskaźnika. Spowodowane jest to tym, że prace z zakresu historii gospodarczej i demografii historycznej wykazują nieco odmienny rozkład cyfry wiodącej niż klasyczny rozkład Benforda, a największa różnica występuje przy cyfrze 1. Dodanie tych „brakujących” jedynek powoduje lepsze dostosowanie danych do rozkładu. Jaka jest zatem granica, poza którą można mieć wątpliwości co do rzetelności danych źródłowych? Sądzę, że powyżej 0,02 KL lub powyżej 10 indeksu W należy uważać dane za wątpliwe, a im wyższe wartości, tym większe jest prawdopodobieństwo, że dane zostały intencjonalnie zmienione. Na wykresie 2 przedstawiono zależność między udziałem losowych cyfr wiodących a wartością indeksu W. Dodatkowo szarym prostokątem zaznaczono dane, które mogą być uważane za prawidłowe.

Omówiona metoda analizy poprawności danych źródłowych jest wprawdzie ograniczona do liczb, ale stanowi nowe narzędzie, które historyk może zastosować do krytyki wewnętrznej źródeł o charakterze masowym. Do tej pory nie była ona wykorzystywana w badaniach historycznych, a jej zastosowanie było ograniczone do audytu danych ekonomicznych lub podatkowych. Aby zweryfikować jej przydatność, należy ją wypróbować na większej liczbie różnego rodzaju źródeł masowych pochodzących z różnych epok historycznych. Liczba baz danych zawierających tego typu informacje rośnie z roku na rok, przez co konieczne staje 
Wykres 2. Udział losowych cyfr wiodących a wartość indeksu W

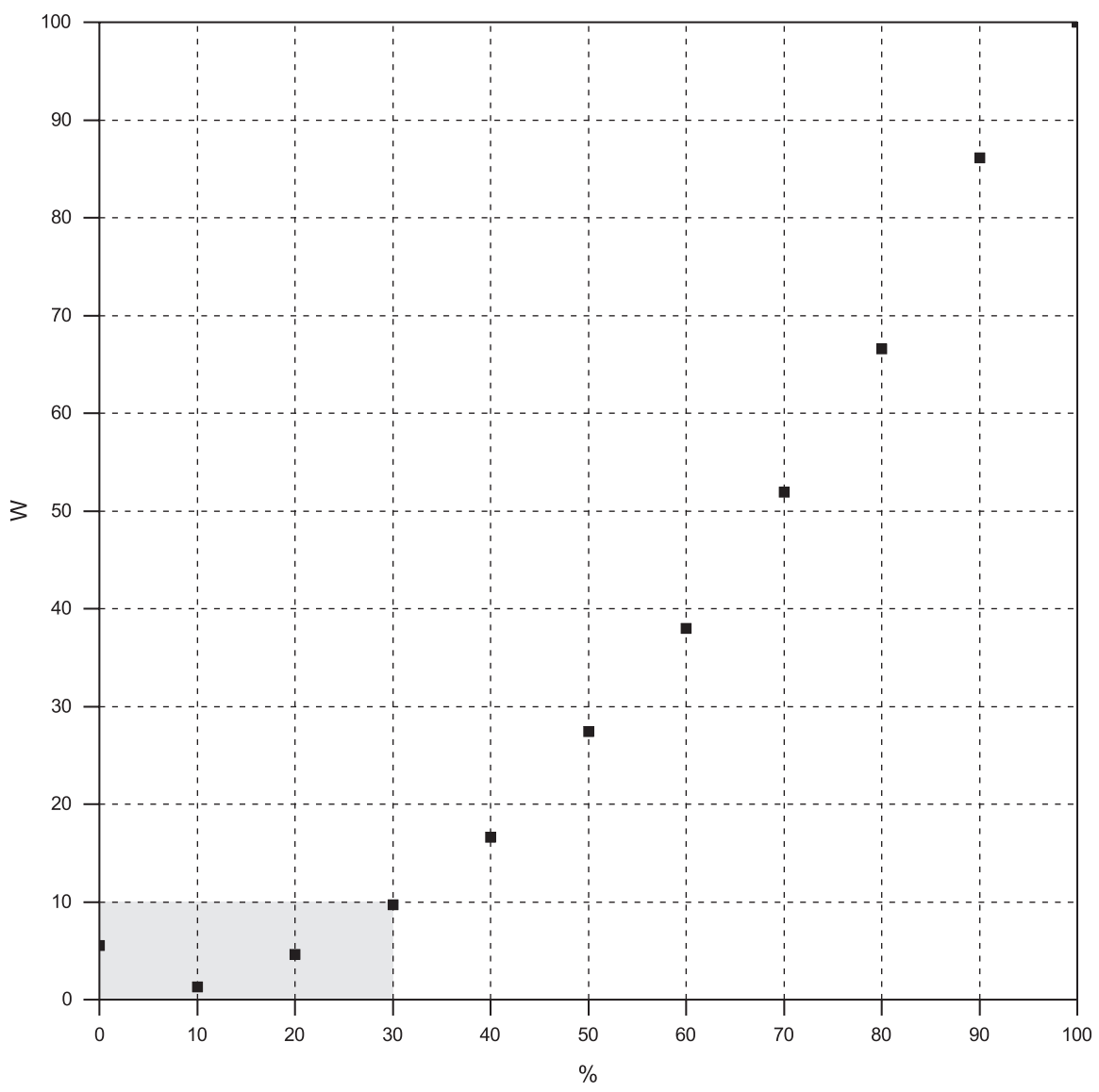

Opracowanie własne.

się posiadanie narzędzi mogących określić ich wiarygodność. Tym bardziej że często słyszy się opinie, iż źródła pochodzące ze starszych epok czy też źródła typu podatkowego są mniej lub mało dokładne lub wręcz niektóre z nich zostały sfałszowane. Być może dokładniejsza analiza ich treści i zgodności rozkładu cyfr wiodących z rozkładem Benforda doprowadzi nas do innych wniosków.

\section{Bibliografia}

\section{Źródla internetowe}

http://www.censusmosaic.org/mosaic/tmp/download/Datafile_06\%20Version\%20 1.0.zip. Dostęp 15.03.2017. 
http://www.jstor.org/stable/986530.http://hgisb.kul.lublin.pl/agad/rejestry/rejestry kcn16w.xls. Dostęp 15.03.2017.

\section{Literatura}

Benford, Frank. „The Law of Anomalous Numbers”. Proceedings of the American Philosophical Society 78 (1938), 4: 551-572.

Campbell, William Wallace. „Biographical Memoir Simon Newcomb 1835-1909”. National Academy of Sciences, 1916. Dostęp 20.03.2017. http://www.nasonline.org/publications/biographical-memoirs/memoir-pdfs/newcomb-simon.pdf.

Cover, Thomas M., Joy A. Thomas. Elements of Information Theory. New York: Wiley, 1991.

Diaconis, Persi. „The Distribution of Leading Digits and Uniform Distribution Mod 1”. The Annals of Probability 5 (1977), 1: 72-81. Dostęp 20.30.2017. http://www.jstor. org/stable/2242803.

Fewster, Rachel M. „A Simple Explanation of Benford's Law”. The American Statistician 63 (2009), 1: 26-32. Dostęp 20.30.2017. http://www.jstor.org/stable/27644089.

Hill, Theodore P. „Base-invariance Implies Benford's Law”. Proceedings of the American Mathematical Society 123 (1995), 3: 887-895.

Judge, George, Laura Schechter. „Detecting Problems in Survey Data Using Benford's Law”. The Journal of Human Resources 44 (2009), 1: 1-24. Dostęp 23.03.2017. http:// www.jstor.org/stable/20648886.

Kula, Witold. Problemy i metody historii gospodarczej. Warszawa: PWN, 1963.

Logan, Jonothan L., Samuel A. Goudsmit. „The First Digit Phenomenon”. Proceedings of the American Philosophical Society 122 (1978), 4: 193-197. Dostęp 20.30.2017. http://www.jstor.org/stable/986530.

Newcomb, Simon. „Note on the Frequency of Use of the Different Digits in Natural Numbers". American Journal of Mathematics 4 (1881), 1: 39-40.

Norberg, Arthur L. „Simon Newcomb’s Early Astronomical Career”. Isis 69 (1978), 2: 209-225. Dostęp 23.03.2017. http://www.jstor.org/stable/230430.

Pericchi, Luis, David Torres. „Quick Anomaly Detection by the Newcomb-Benford Law, with Applications to Electoral Processes Data from the USA, Puerto Rico and Venezuela”. Statistical Science 26 (2011), 4: 502-516. Dostęp 23.03.2017. http://www. jstor.org/stable/23208738.

Raimi, Ralph A. „The First Digit Phenomenon Again”. Proceedings of the American Philosophical Society 129 (1985), 2: 211-219. Dostęp 23.03.2017. http://www.jstor. org/stable/986989.

Raimi, Ralph A. „The First Digit Problem”. The American Mathematical Monthly 83 (1976), 7: 521-538.

Szołtysek, Mikołaj. Rethinking East-Central Europe: family systems and co-residence in the Polish-Lithuanian Commonwealth. Vol. 1-2. Bern: Peter Lang, 2015.

Wnęk, Konrad. Własność nieruchomości w Krakowie w połowie XIX w. Kraków: Historia Iagellonica, 2011. 


\section{Metoda badania wiarygodności masowych źródeł historycznych, baz danych i opracowań badawezych}

\section{Streszczenie}

W artykule przedstawiono metodę zastosowania prawa Benforda w celu weryfikacji rzetelności źródeł historycznych i opracowań badawczych zawierających wiele danych liczbowych. Prawo to wykorzystuje rozkład cyfry wiodącej w dużym zbiorze danych, który nie jest - jak można by przypuszczać - rozkładem losowym. Badania przeprowadzono na czterech przykładach źródeł i publikacji historycznych. W przypadku trzech z nich potwierdzono zgodność empirycznych rozkładów cyfry wiodącej z rozkładem Benforda; na przykładzie czwartej natomiast wskazano ograniczenia tej metody weryfikacji w odniesieniu do opracowań, w których dane pierwotne podlegają kodowaniu. Nie może też być ona stosowana dla liczb losowych oraz dla zjawisk zbliżonych do rozkładu normalnego. Opracowano również syntetyczną miarę zgodności rozkładów wykorzystującą tzw. entropię względną (dywergencję Kullbacka-Leiblera) w postaci indeksu wiarygodności W. Wskaźnik ten może przyjmować wartości teoretyczne od 0 do 100, choć W szczególnych przypadkach może nawet tę górną granicę przekraczać. Zaproponowano również wartość graniczną wskaźnika W, od której można mieć uzasadnione wątpliwości co do wiarygodności danych.

Słowa kluczowe: krytyka źródeł, badania masowe, demografia historyczna, bazy danych, Benford

\section{Method of testing the reliability of mass historical sources, databases and research studies}

\section{Summary}

The paper presents the method of applying the Benford law to verify the reliability of historical sources and research papers containing many numbers. This law uses the distribution of the leading number in a large data set, which is not a random distribution as one would assume. The study was carried out using four examples of historical sources and publications. Three of them confirmed that the empirical distribution of the leading digit was in line with the Benford distribution; the example of the fourth one indicated the limitations of this verification method for studies in which primary data are encoded. It cannot be used for random numbers and for phenomena similar to normal distribution. The author of the paper has also constructed a synthetic measure of concordance of distributions, which makes use of relative entropy (the Kullback-Leibler divergence) in the form of a W - validity index. This index may take theoretical values from 0 to 100 , 
although in some cases it may even exceed this upper limit. The study also proposes a limit value for the $\mathrm{W}$ index, from which reasonable doubt about the reliability of the data may arise.

Keywords: criticism of historical sources, mass research, historical demography, databases, Benford's law 
Budowane na tej podstawie zarówno przez twórcę metody, jak i późniejszych badaczy modele wskazywały, że przy dostatecznie dużej liczbie obserwacji i dobrej jakości rejestracji umieralność endogeniczna nie powinna być niższa niż $15 \% 0^{6}$. Ta druga własność modelu została wykorzystana do detekcji niedorejestracji zgonów niemowląt $w$ pierwszych czterech tygodniach życia (a więc zazwyczaj przed chrztem i wpisem do ksiąg metrykalnych), znacząco zaniżającej wymiar umieralności endogenicznej’. Oznacza to, że zarówno bezwzględnie niskie wartości parametru $a$, jak i relatywnie niewielki jego udział w skumulowanym współczynniku umieralności na koniec 12 . miesiąca życia powinny wzbudzić podejrzenia badacza, iż ma on do czynienia $z$ danymi wadliwymi. Jednak zamiast wyłącznie stawiać sztywne granice wartościom parametrów modelu, świadczące o wiarygodności bądź wadliwości danych, najlepiej odnieść uzyskane wyniki do szacunków dla możliwie zbliżonych chronologicznie i geograficznie populacji, których źródła demograficzne są uznawane za dane o wysokiej jakości. Warto również zwrócić uwagę na względną stabilność w czasie umieralności endogenicznej, gdyż ta, w odróżnieniu od umieralności egzogenicznej i ogólnej, nie powinna być wrażliwa na zmiany koniunktury gospodarczej czy klęski elementarne.

Trzecia własność modelu bazuje na przekonaniu o ochronnych właściwościach naturalnego karmienia niemowląt i o negatywnym wpływie odstawienia naturalnego pokarmu na zdrowie dzieci. Liczne studia nad umieralnością niemowląt pokazały bowiem, że uogólnienie dokonane przez Bourgeois-Pichata nie zawsze dobrze oddawało rozwój umieralności dzieci w pierwszym roku życia ${ }^{8}$. W przypadku niektórych populacji obserwowano bardzo charakterystyczny

${ }^{6}$ Za przykład można tu podać przytaczane przez Jeana Bourgeois-Pichata dane odnośnie do Danii, Szwecji czy Francji z początków XX wieku. Zob. Bourgeois-Pichat, „La mesure de la mortalité infantile. I”. Zob. również Paul Huck, „Infant Mortality and Living Standards of English Workers during the Industrial Revolution", The Journal of Economic History 55 (1995), 3: 528 550; Susan Scott, Christopher J. Duncan, „Malnutrition, Pregnancy, and Infant Mortality: A Biometric Model", The Journal of Interdisciplinary History 30 (1990), 1: 37-60; Katherine A. Lynch, Joel B. Greenhouse, Anders Brändström, „Biometric Modeling in the Study of Infant Mortality: Evidence from Nineteenth-Century Sweden", Historical Methods: A Journal of Quantitative and Interdisciplinary History 31 (1998), 2: 53-64. Dla miast francuskich: Robert Nadot, „Évolution de la mortalité infantile endogène en France dans la deuxième moitié du XIXe siècle”, Population 25 (1970), 1: 49-58.

${ }^{7}$ Edward A. Wrigley, „Births and Baptisms: The Use of Anglican Baptism Registers as a Source of Information about the Numbers of Births in England before the Beginning of Civil Registration”, Population Studies 31 (1977), 2: 281-312; Huck, „Infant Mortality”.

${ }^{8}$ Przegląd tych studiów zob. John Knodel, Hallie Kintner, „The Impact of Breast Feeding Patterns on the Biometric Analysis of Infant Mortality”, Demography 14 (1977), 4: 391-409. Nowsze studia pokazują również, iż wyniki modelu mogą nie być wiarygodne w wypadku silnego oddziaływania klimatu na umieralność niemowląt - zob. Matteo Manfredini, „The Bourgeois-Pichat's Biometric Method and the Influence of Climate: New Evidences from Late 19th-century Italy", Social Biology 51 (2004), 1-2: 24-36. 